\title{
Acute Toxicity Evaluation of the Malagasy Endemic Aloe helenae and A. analavelonensis in Mice
}

\author{
Rokiman Letsara ${ }^{1}$, Rigobert Andrianantenaina ${ }^{2}$, Colette Masengo Ashande ${ }^{3}$, Clarisse \\ Falanga Mawi ${ }^{4}$, M. Yoserizal Saragih ${ }^{5}$, Koto-te-Nyiwa Ngbolua ${ }^{6}$, Baholy Robijaona \\ Rahelivololoniaina ${ }^{7}$ \\ ${ }^{1}$ Parc Botanique et Zoologique de Tsimbazaza (PBZT), Antananarivo, Madagascar \\ ${ }^{1,7}$ Engineering and Industrial Process, Agricultural and Food Systems, Polytechnic High School of \\ Antananarivo, Madagascar (ESPA) \\ ${ }^{2}$ Centre National de Recherches sur l'Environnement (CNRE) \\ ${ }^{3,6}$ Department of Environmental Sciences, Faculty of Science, University of Gbado-Lite, Gbado-Lite, \\ Democratic Republic of the Congo \\ ${ }^{4,6}$ Department of Biology, Faculty of Science, University of Kinshasa, Kinshasa, Democratic Republic of \\ the Congo \\ ${ }^{5}$ Universitas Islam Negeri Sumatera Utara, Medan, Indonesia \\ holyrobi@gmail.com
}

\begin{abstract}
The therapeutic virtues of medicinal plants are known and used in Africa and in Madagascar where natural products form the basis of Traditional Medicine. More than 300 million people worldwide consume dietary supplements and herbal plants. Scientific studies confirm that Aloes contains pharmacologically active ingredients associated with diverse biological activities including fungicidal, antiviral, antibacterial, anti-inflammatory, antimicrobial, laxative, immunomodulating, and anticancer effects. The aim of the present study was to evaluate the effects of orally administered extracts of two Aloe species: A. helenae, A. analavelonensis on mice. Mice were gavaged with crude whole leaves extracts after 24 hours of empty stomach. The extracts administration was found to be not acute toxic at the dose $1200 \mathrm{mg} / \mathrm{kg}$ with 100\% survival of mice. Since the Aloe helenae is traditionally used against intestinal worms in sheep and goats, it is thus desirable that the plant species could be submitted to phytochemical for the isolation and characterization of new antihelminthic compounds.
\end{abstract}

Keywords : aloe; leaf extract; non-toxicity

\section{Introduction}

The therapeutic virtues of medicinal plants are known and used everywhere, especially in countries like Madagascar where these natural products form the basis of Traditional Medicine [1]. More than 300 million people worldwide consume dietary supplements and herbal plants [2]. Scientific studies confirm that Aloes contains pharmacologically active ingredients associated with diverse biological activities including fungicidal, antiviral, antibacterial, anti-inflammatory, antimicrobial, laxative, immunomodulating, and anticancer effects [3-5]. It is also employed as a dietary supplement in a variety of foods and as an ingredient in cosmetic products [6]. Due to its phytochemistry compounds, a non-native and extensively cultivated Aloe vera (L.) Burm.f. (syn.: Aloe barbadensis Miller) is reported to have an antioxidant propriety [7]. It is already known that Aloe species like A. vera whole leaf extract, including the gel and the latex, contains more than 200 chemical substances [8]. Dee et al., 2018 [9] reported 132 native Aloe spp., all of which are endemic to Madagascar and consider the island as a major center of diversity of Aloe. All these observations aroused our curiosity to better understand the Malagasy medicinal and endemic plant of the genus Aloe on a scientific level because of its use in an anarchic way in Traditional Medicine. Since the Aloe helenae has been used locally for treating intestinal worms in sheep and goats, this study is a good perspective in that way. The Thin Layer Chromatography profiling of some Malagasy Aloe leaves extracts studies has shown an evident antioxidant activity in Aloe 
helenae [10]. In addition, the threat of this plants habitat that colonize all major habitats in Madagascar [11] and the resurgence of needs of local residents who clear the entire forest for their daily needs in order to manage their crops may cause the plant to disappear. In this context, the general objective of this study is to make sure that dietary or herbal supplement products are expected to be safe, effective, and of appropriate quality; also to enhance these plants in order to contribute to its rational use and its conservation. In fact, the potential uses of plant as alternative remedies in the treatment of many infectious diseases and as a means of preserving food from oxidation processes have been highlighted in several reports [12].

Thus, the study of the biological activities of extracts from these plants is one of the main means of commercially enhancing them or validating their use in Traditional Medicine; the chapter will be devoted to the study of the toxicity of the extracts of these two Aloes.

\section{Material and Methods}

\subsection{Plant Material}

Fresh leaves of Aloe analavelonensis (figure 1a) and Aloe helenae (figure 1b) were sourced from the garden of the "Parc Botanique et Zoologique de Tsimbazaza, Antananarivo, Madagascar". A. analavelonesis is an endangered plant categorized in "Vulnerable" status [13]. It has a very restricted occurrence in the wild in a particular remote area only from Analavelona Humid Forest inside the Western Dry area in the South West of Madagascar. This forest is object of local based management protected area.
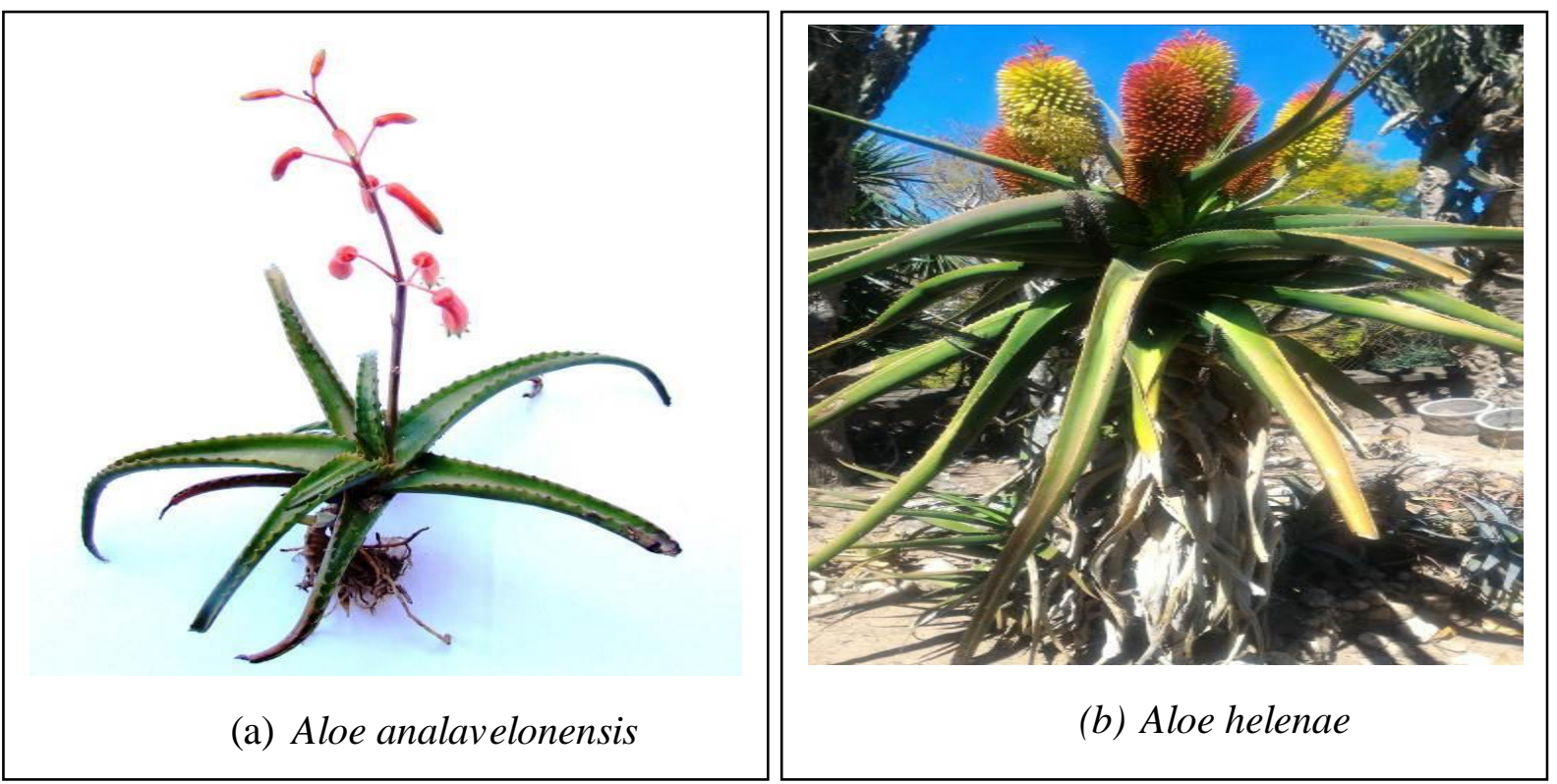

Figure 1. Photography of Studied Aloes [10]

A. helenae otherwise occurs in the Dry South East of Madagascar. It is classified as an "Endangered" plant [14] in the category of the Red List Threatened Species of the International Union for Conservation of Nature (IUCN). This species is also protected by the Appendix I of the Convention on International Trade in Endangered Species of Wild Fauna and Flora, commonly abbreviated as CITES. 


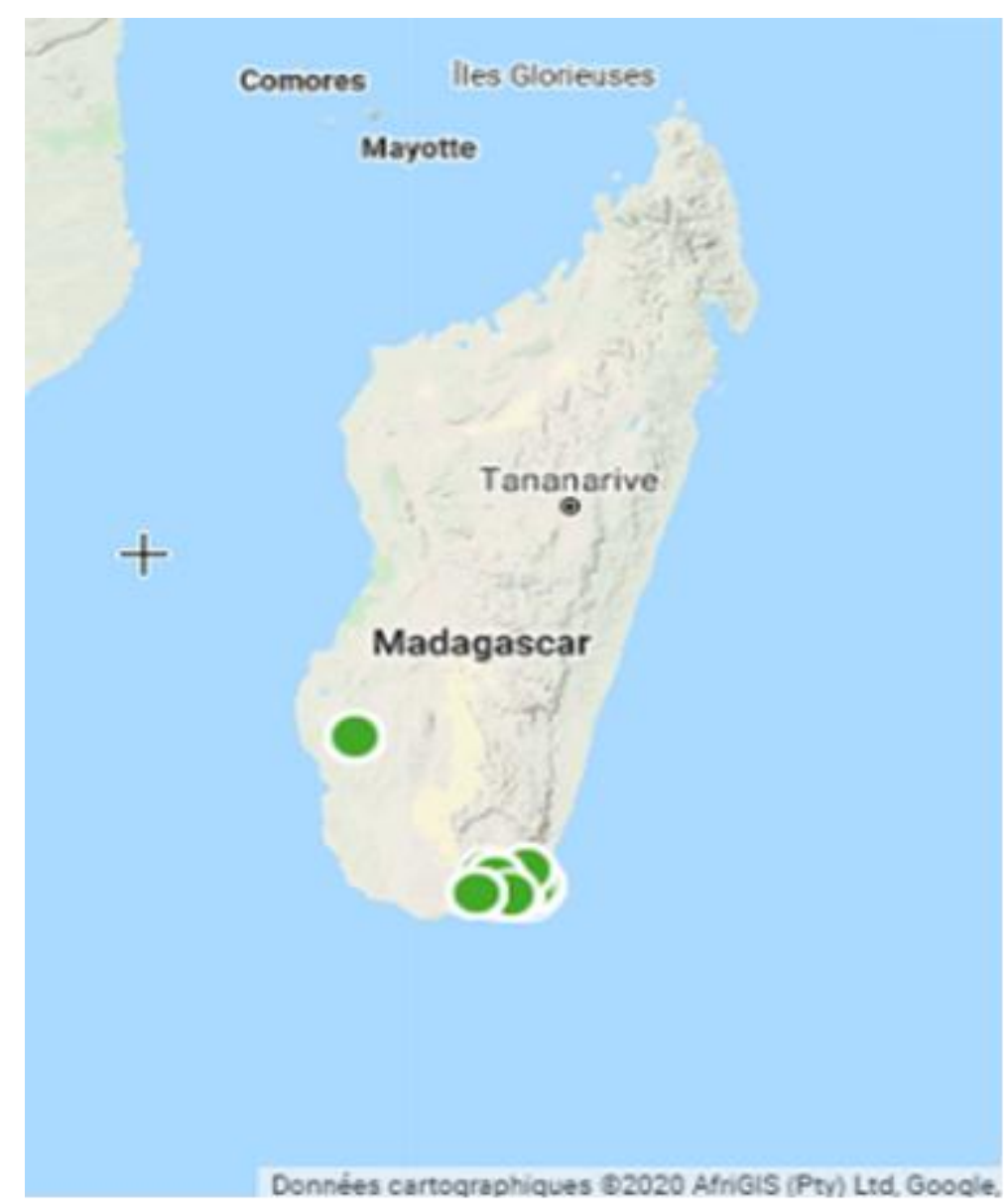

Figure 2. Distribution Map of the Two Aloes in Their Habitat in Madagascar

\subsection{Collection and Preparation of the Plant Extracts}

Fresh whole leaves were collected at 6 a.m in the morning. Samples were stored at the temperature of $-20{ }^{0} \mathrm{C}$ before extraction. Afterwards, these leaves were dried by lyophilisation (Temperature $-40{ }^{0} \mathrm{C}$ under pressure $0,850 \mathrm{mBar}$ during 6 days). Crude extracts were prepared from the dry powdered samples. Each powder was extracted from $100 \mathrm{~mL}$ of ethanol $80^{\circ}$ at a temperature of $70{ }^{\circ} \mathrm{C}$ for 1 hour.

\subsection{Laboratory Animal Used}

The in vivo study was carried out on Swiss breed mice (Mus musculus), obtained from the animal house of the Institut Malgache des Vaccins Vététinaires (IMVAVET) and bred at the PBZT. The mice are housed in cages where they have free access to water and food. Mice of different sexes of avarage weight between $22-23 \mathrm{~g}$ (6 to 8 weeks age), were dosed orally with $1,200 \mathrm{mg} / \mathrm{kg}$ body weight of plant extract.

\subsection{Acute Toxicity Assessment}

The determination of acute toxicity consists in knowing the single lethal dose of the extract at one time in a determined time $(24 \mathrm{~h})$. Trevan's method [15] was used to determine the $\mathrm{LD}_{50}$, given by the curve of percentage mortality of mice as a function of the decimal logarithm of the doses administered. The values found are then confirmed by the calculation method of Berhens and Karber [16]: $\mathrm{LD}_{50}=\left[\mathrm{LD}_{100}-\Sigma(\mathrm{a} X \mathrm{X})\right] / \mathrm{n}$ ', with n' the average number of animals per batch, a, the average of deaths between doses and $b$, the difference between two successive doses. The toxicity values scale used to locate the toxicity effect of extracts is given in table 1. Animals were selected by stratified randomization and then 
divided into three groups of three mice each. Groups II and III were given 1,200 $\mathrm{mg} / \mathrm{kg}$ body weight of each plant extract orally (force-feeding at a rate of $0.3 \mathrm{~mL}$ ) in a single dose. $\mathrm{NaCl} 0.9 \%$ served as the vehicle and was used to prepare the dose. Group I served as the control group and received the $\mathrm{NaCl} 0.9 \%$ vehicle only. The mice were fasted for 24 hours before administration of the extracts. They were observed for 24 hours for signs of toxicity, mortality and general behaviours. Animals were fed ad libitum with standard feed, and had free access to water. They were also maintained under standard conditions of humidity, temperature, and 12 hours light/dark cycle. The animals were acclimatized for a week before the commencement of the study. A standard protocol was drawn up in accordance with current guidelines for the care for laboratory animals and ethical guidelines for investigations of experiments in conscious animals. The first day of dosing was taken as day 0. During the two-week period, all the animals were observed daily for clinical signs and mortality patterns once before dosing, immediately after dosing and up to two to four hours after dosing [17].

Table 1. Toxicity Class, According to the Hodge and Sterner Toxicity Scale [18]

\begin{tabular}{cll}
\hline $\begin{array}{c}\text { Toxicity index or } \\
\text { class }\end{array}$ & Commonly used term & Toxicological parameter $\left(\mathrm{LD}_{50}\right)$ \\
\hline 1 & Extremely toxic & $\mathrm{LD}_{50} \leq 1 \mathrm{mg} / \mathrm{Kg}$ \\
2 & Highly toxic & $1 \mathrm{mg} / \mathrm{Kg} \leq \mathrm{LD}_{50} \leq 50 \mathrm{mg} / \mathrm{Kg}$ \\
3 & Moderately toxic & $50 \mathrm{mg} / \mathrm{Kg} \leq \mathrm{LD}_{50} \leq 500 \mathrm{mg} / \mathrm{Kg}$ \\
4 & Slightly toxic & $500 \mathrm{mg} / \mathrm{Kg} \leq \mathrm{LD}_{50} \leq 5 \mathrm{~g} / \mathrm{Kg}$ \\
5 & Almost toxic & $5 \mathrm{~g} / \mathrm{Kg} \leq \mathrm{LD} D_{50} \leq 15 \mathrm{~g} / \mathrm{Kg}$ \\
6 & Relatively harmless & $\mathrm{LD}_{50} \geq 15 \mathrm{~g} / \mathrm{Kg}$ \\
\hline
\end{tabular}

\section{Results and Discussion}

\subsection{Clinical Signs Noted After Force-Feeding the Crude Extracts}

A few moments after gavage of plant extracts at a dose of $1200 \mathrm{mg} / \mathrm{Kg}$, a lack of appetite, motor difficulties and amplitudes of respiratory voice were noted. This behavior can be explained by the altered physiological processes for transient period due to administered dose.

About twenty minutes later, all the animals resumed their normal behaivour. This shows that the plant extract seems to exert a stressful effect on the mice.

\subsection{Effect of Gavage of the Extract on the Mortality of Mice}

During the present investigation, the extracts of the two Aloes administered at a dose of 1200 $\mathrm{mg} / \mathrm{Kg}$, did not cause the death of the mice.

\subsection{Determination of the $\mathbf{L D}_{50}$}

The $\mathrm{LD}_{50}$ which is the dose causing the death of $50 \%$ of the mice could not be determined.

In fact, no mouse died at the dose of $1200 \mathrm{mg} / \mathrm{kg}$; the $\mathrm{LD}_{50}$ would therefore be higher than this dose. The present study revealed that the tested plant materials are not (slightly) toxic to mice. It is obvious that the results obtained on mice cannot be applied directly to humans; however, these results reassure the safety of the two plant extracts.

The Maximum Tolerated Dose (MTD) is higher than $1200 \mathrm{mg} / \mathrm{kg}$ and could therefore potentially be used experimentally in a subacute or chronic toxicity study. Thus, the value of the lethal dose 50 greater than $1200 \mathrm{mg} / \mathrm{Kg}$ of body weight in mice makes it possible to classify the extracts as slightly toxic substance, on the classified toxicity scale of Hodge and Sterner as reported by Cotonat [19].

In addition, for this $\mathrm{LD}_{50}$ value, a $50 \mathrm{~kg}$ person should receive at least $1200 \mathrm{mg} / \mathrm{Kg}$ x 50 , i.e. $60,000 \mathrm{mg}$ of product in a single dose to run the same symptoms. These $60 \mathrm{~g}$ dose of extract on the Gosselin Smith and Hodge classification scale could be classified as non-toxic to humans. A. helenae is acclaimed by traditional healers to be efficacious and have been used by local people for 
decades. Thus, the two tested plant species may be recommended for the management of helminthiasis. Mpiana et al. (2020) [5] revealed that some Aloe derived compounds are potential inhibitors of the main protease (3CLpro) responsible for the replication of coronaviruses. Our previous work revealed that the plant of the Aloe helenae possess antioxidant properties [10] and could be used as anti-oxidative therapy for alliviating injuries in patients infected by Coronavirus. It also was reported that some plants belonging to Aloe genus has a large abroad of antiviral activity including coronavirus SARS-CoV-1 and are widely consumed orally and are safe [4]. Thus, Malagasy endemic Aloes could also be used as nutraceuticals by associating them with Moringa as fortifiant for solving helminthias problem in pregnant women [20].

\section{Conclusion and Suggestions}

The crude extracts of $A$. helenae and A. analavelonensis have shown a slightly toxic activity giving thus the possibility of their use as phytomedicines at the dose below $1200 \mathrm{mg} / \mathrm{Kg}$ of body weight. Since the Aloe helenae is traditionally used against intestinal worms in sheep and goats, it is thus desirable that the plant species could be submitted to phytochemical for the isolation and characterization of new antihelminthic compounds.

\section{Acknowledgements}

The authors are indebted to Tsimbazaza Botanical \& Zoological park, Polytechnic High School of Antananarivo and National Research Centre on the Environment (Madagascar) and University of Kinshasa and University of Gbado-Lite (Democratic Republic of the Congo) for the assistance.

\section{References}

1. Turbide M. L'aromathérapie: applications thérapeutiques, les huiles du Québec et du monde ; Montréal, 2010. (http://sante-arome.com).

2. Bailey RL, Gahche JJ, Lentino CV, Dwyer JT, Engel JS, Thomas PR, Betz JM, Sem- pos CT, Picciano MF. Dietary supplement use in the United States, 2003-2006. J Nutr. 2011; 141: 261-266.

3. Cosmetic Ingredient Review Expert Panel. Final report on the safety assessment of Aloe andongensis extract, $A$. andongensis leaf juice, A. arborescens leaf extract, A. arborescens leaf juice, A. arborescens leaf protoplasts, A. barbadensis flower extract, A. barbadensis leaf, $A$. barbadensis leaf extract, $A$. barbadensis leaf juice, $A$. barbadensis leaf polysaccharides, $A$. barbadensis leaf water, $A$. ferox leaf extract, $A$. ferox leaf juice, and $A$. ferox leaf juice extract. Int J Toxicol. 2007; 26(Suppl 2):1-50.

4. Mpiana PT, Ngbolua KN, Tshibangu DST, Kilembe JT, Gbolo BZ, Mwanangombo DT, Inkoto CL, Lengbiye EM, Mbadiko CM, Matondo A, Bongo GN, Tshilanda DD. Aloe vera (L.) Burm. F. as a Potential Anti-COVID-19 Plant: A Mini-review of Its Antiviral Activity. European Journal of Medicinal Plants, 2020; 31(8): 86-93.

5. Mpiana PT, Ngbolua KN, Tshibangu DST, Kilembe JT, Gbolo BZ, Mwanangombo DT, Inkoto CL, Lengbiye EM, Mbadiko CM, Matondo A, Bongo GN, Tshilanda DD. Identification of potential inhibitors of SARS-CoV-2 main protease from Aloe vera compounds: a molecular docking study, Chemical Physics Letters, 2020; doi: https://doi.org/10.1016/j.cplett.2020.137751. 
6. Xiaoqing G, Nan M, 2016. Aloe vera: A review of toxicity and adverse clinical effects. J Environ Sci Health C Environ Carcinog Ecotoxicol Rev., 2016; 34(2): 77-96. doi: 10.1080/10590501.2016.1166826.

7. Miladi S, Mohamed D. In vitro antioxidant activities of Aloe vera leaf skin extracts. Journal de la Société Chimique de Tunisie, 2008; 10: 101-109.

8. Dee R. A phylogenetic analysis of the genus Aloe (Asphodelaceae) in Madagascar and the Mascarene Islands. Botanical Journal of the Linnean Society, 2018; 187(3):428-440.

9. Rodriguez Rodriguez E, Darias Martin J, Diaz Romero C. Aloe vera as a functional ingredient in foods. CritRev Food Sci Nutr., 2010; 50:305-326.

10. Letsara R, Andrianantenaina R, Bongo GN, Ashande CM, Matondang MI, Ngbolua KN, Robijaona RB. TLC Profiling of Leaves Extracts of Some Aloe Threatened Species Endemic to Madagascar for Their Antioxidant Activity. Britain International of Exact Sciences (BIoEx) Journal, 2020; 2(3): 653-662.

11. Orlando G. Aloes of Madagascar. ALOE, 2013; 50 (1\&2): 61-67.

12. Kelen M, Tepe B. Chemical composition, antioxidant and antimicrobial properties of the essential oils of three Salvia species from Turkish flora. Bioresource Technology, 2008; 99: 4096-4104.

13. Letsara R, Rakotoarisoa SE, Almeda F. Three new Aloe species from Madagascar. Malagasy Nature, 2012; 6: 46-55.

14. Rakotoarisoa SE. Aloe helenae. IUCN Red List of Threatened Species. 2016: e.T39056A69007588. doi:10.2305/IUCN.UK.2016-3.RLTS.T39056A69007588.en

15. Trevan J. The error of determination of toxicity. Proc R Soc., 1927; 101B: 483-514.

16. Gosselin RE, Smith RP, Hodge HC. Clinical Toxicology of Commercial Products., 5e éd. Baltimore (MD): Williams and Wilkins. p. II330, 1984.

17. Ngbolua KN, Mpiana PT, Tshibangu DST, Mazasa PP, Gbolo BZ, Atibu EK, Kadima JN, Kasali FM. In vitro anti-sickling and radical scavenging activities of a poly-herbal formula (Drepanoalpha®) in Sickle cell erythrocyte and acute toxicity study in Wistar albino rats. European Journal of Medicinal Plants, 2014; 4(10): 1251-1267.

18. Hodge HC, Sterner JH. Determination of substances acute toxicity by LDB50B. Amer. Industrial Hyg. Assoc., 1943; 10: 93.

19. Cotonat J. La toxicologie, Paris, Presses Universitaires de France (PUF), 1996.

20. Randrantoarimbola L, Rafalimanantsoa J, Ratiarimananjatovo N, Randriamanantena AA, Bongo N, Ngbolua KN, Robijaona B. Formulation of Moringa oleifera Lam. based Biofortified Food Supplement for Pregnant Women in Madagascar, Indian Ocean. Britain International of Exact Sciences (BIoEx) Journal, 2020; 2(2): 533-540. 